CASE REPORT

\title{
Homozygous mutation of the IGF1 receptor gene in a patient with severe pre- and postnatal growth failure and congenital malformations
}

\author{
Marie-Hélène Gannagé-Yared*, Jürgen Klammt ${ }^{1, *}$, Eliane Chouery ${ }^{2}$, Sandra Corbani $^{2}$, Hala Mégarbané ${ }^{3}$, \\ Joelle Abou Ghoch ${ }^{2}$, Nancy Choucair ${ }^{2}$, Roland Pfäffle ${ }^{1}$ and André Mégarbané Mé $^{2,4}$ \\ Service d'Endocrinologie, Hôtel-Dieu de France Hospital, Beirut, Lebanon, ${ }^{1}$ Hospital for Children and Adolescents, University of Leipzig, Leipzig, Germany, \\ ${ }^{2}$ Unité de Génétique Médicale et Laboratoire Associé INSERM UMR_S910, Faculté de Médecine, Pôle Technologie Santé, Université Saint-Joseph, Beirut, \\ Lebanon, ${ }^{3}$ Department of Dermatology, Saint Georges Hospital, University of Balamand, Beirut, Lebanon and ${ }^{4}$ Institut Jérôme Lejeune, Paris, France \\ (Correspondence should be addressed to A Mégarbané at Unité de Génétique Médicale et Laboratoire Associé INSERM UMR_S910, \\ Université Saint-Joseph; Email: megarbane@usj.edu.lb) \\ *(M-H Gannagé-Yared and J Klammt contributed equally to this work)
}

\begin{abstract}
Background: Heterozygous mutations in the IGF1 receptor (IGF1R) gene lead to partial resistance to IGF1 and contribute to intrauterine growth retardation (IUGR) with postnatal growth failure. To date, homozygous mutations of this receptor have not been described.

Subject: A 13.5-year-old girl born from healthy first-cousin parents presented with severe IUGR and persistent short stature. Mild intellectual impairment, dysmorphic features, acanthosis nigricans, and cardiac malformations were also present.

Methods: Auxological and endocrinological profiles were measured. All coding regions of the IGF1R gene including intron boundaries were amplified and directly sequenced. Functional characterization was performed by immunoblotting using patient's fibroblasts.

Results: IGF1 level was elevated at $950 \mathrm{ng} / \mathrm{ml}$ ( +7 s.D.). Fasting glucose level was normal associated with high insulin levels at baseline and during an oral glucose tolerance test. Fasting triglyceride levels were elevated. Sequencing of the IGF1R gene led to the identification of a homozygous variation in exon 2: c.119G > T (p.Arg10Leu). As a consequence, IGF1-dependent receptor autophosphorylation and downstream signaling were reduced in patient's fibroblasts. Both parents were heterozygous for the mutation. Conclusion: The homozygous mutation of the IGF1R is associated with severe IUGR, dysmorphic features, and insulin resistance, while both parents were asymptomatic heterozygous carriers of the same mutation.
\end{abstract}

European Journal of Endocrinology 168 K1-K7

\section{Introduction}

Intrauterine growth retardation (IUGR) is defined as a birth weight and/or length more than 2 s.D. below the mean corrected for gestational age (1). This finding reflects pathological processes that inhibit growth in utero. However, only $10 \%$ of these children are at risk for short stature as adults and the cause of this postnatal defect often remains unclear (2).

Insulin-like growth factor 1 (IGF1) and IGF1 receptor $(I G F 1 R)$ gene defects have been identified in a few patients with IUGR. Severe IGF1 deficiency due to a homozygous mutation in the IGF1 gene results in intrauterine and postnatal growth failure, microcephaly, intellectual disability, and deafness $(3,4,5,6)$. Mutations in the IGF1R gene in the heterozygous state have been recently described as a cause of IUGR (7) and lead to partial resistance to IGF1 and contribute to IUGR with postnatal growth failure, microcephaly, and normal or increased levels of serum IGF1 and IGF binding protein 3 (IGFBP3), sometimes associated with modestly impaired intellectual development $(8,9,10$, $11,12,13,14,15,16,17,18,19,20,21)$. Skeletal and cardiac abnormalities might also be mainly present in patients with terminal deletion of chromosome $15 q$ including the IGF1R locus (22), but these conditions are possibly caused by deletion of other genes. So far, only two patients were described with a compound heterozygous mutation in the IGF $1 R$ gene $(8,20)$ while mutations in the homozygous state have never been reported. Here, we report for the first time the case of a 13.5-year-old girl harboring a homozygous mutation of the IGF1R gene presenting with severe IUGR and postnatal growth failure. 


\section{Materials and methods}

\section{Subject}

The patient is the only child of healthy, first-cousin Lebanese parents. A written consent was obtained from both parents before performing all the analyses. Height and weight were compared with normative French references.

\section{Biochemical analysis}

IGF1, 25(OH)vitamin D (25(OH)D), and parathormone (PTH) were measured using commercial chemiluminescent assays on the automated Diasorin automate (Stillwater, MN, USA). 1,25-Dihydroxyvitamin D3 $(1,25(\mathrm{OH}) 2 \mathrm{D})$ was measured using the Diasorin RIA. IGFBP3, GH, FSH, LH, estradiol $\left(\mathrm{E}_{2}\right)$, free thyroxine $\left(\mathrm{T}_{4}\right)$, $\mathrm{TSH}$, and insulin were measured by commercial chemiluminescent assays (Immulite 2000, Llanberis, Gwynedd, UK). The homeostatic model assessment for insulin resistance index (HOMA-IR = fasting glucose $(\mathrm{mmol} / \mathrm{l}) \times$ fasting insulin $(\mathrm{mIU} / \mathrm{ml}) / 22.5)$ was calculated to assess insulin action (23). Biochemical parameters (serum electrolytes, blood glucose levels, calcium, phosphorus, alkaline phosphatase levels, liver, and renal function tests) were measured using a Kodak automated dry chemistry machine.

\section{Genetic analysis}

EDTA blood samples from the index case and both parents were collected for genetic studies. DNA was extracted from leucocytes by standard salt precipitation methods (24). DNA fragmentation, labeling, hybridization, and scanning were performed according to the manufacturer's protocols (http://www.affymetrix.com) using an Affymetrix Fluidics Station 450, Affymetrix Hybridization Oven 645 and Affymetrix GeneChip Scanner 3000 7G (Affymetrix, Inc., Santa Clara, CA, USA).

The coding sequences of the IGF1R gene (GenBank accession number: NM_000875) and IGF1 (IGF: NM_000618) were sequenced after DNA amplification by PCR. Primers were designed using Primer 3 (http:// frodo.wi.mit.edu) and OLIGOS v.9.3 and checked for specificity using BLAST (http://www.ncbi.nlm.nih.gov/ blast/bl2seq/wblast2.cgi). DNA sequences were obtained from UCSC or GenBank databases. PCR were performed using Taq DNA polymerase (Invitrogen Life Technologies). Nucleotide numbering reflects the open reading frame of the cDNA. Amino acid numbering for IGF1R represents the mature IGF1R protein without the 30 amino acids signal peptide (UniProtKB accession number: P08069). Effects of the sequence variation on the protein were predicted using PolyPhen (http:// genetics.bwh.harvard.edu/pph/).

Wild-type and mutant IGF1R were modeled using the freely available version of the Discovery Studio 3
Software (Accelrys, Inc., San Diego, CA, USA). The crystal structure of the first three domains of the IGF1R protein was obtained from the Protein Data Bank (PDB ID: 1IGR (25)).

\section{Cell culture and immunoblotting}

Patient's and control dermal fibroblasts were cultured in DMEM/F12 supplemented with 10\% FBS under standard conditions. After an overnight starvation in serum-free medium containing $0.2 \%$ BSA, cells were incubated for $15 \mathrm{~min}$ with the indicated concentrations of recombinant human IGF1 (rhIGF1; Biozol, Eching, Germany). Lysates were prepared as described previously (16) followed by SDS-PAGE and immunoblotting to determine IGF1R expression, activation, and signal transduction. Primary antibodies were obtained from New England Biolabs (Frankfurt/ Main, Germany; anti-phospho-IGF1R (Tyr1135/6)/ IR(Tyr1150/1) (19H7); anti-phospho-Akt (Thr308) (244F9); anti-IGF1R $\beta$ (111A9); anti-Akt (9272)) and from Sigma-Aldrich (anti- $\beta$-actin). HRP-conjugated secondary antibodies were from Thermo Fisher Scientific (Bonn, Germany).

\section{Results}

\section{Clinical findings}

The patient was born at 41 weeks of gestation after an unremarkable pregnancy and vaginal delivery, from healthy first-cousin Lebanese parents. At birth, her weight was $1650 \mathrm{~g}$ ( -4.7 S.D.), her length $39 \mathrm{~cm}(-4.5$ s.D. $)$, and her head circumference $30 \mathrm{~cm}$ $(-3.3$ S.D.). A significant systolic murmur was heard. An echocardiogram evidenced an opened foramen ovale (FO), a small perimembraneous ventricular septal defect (VSD), two narrowed pulmonary branch arteries with increased Doppler gradient $(60 \mathrm{~mm} \mathrm{Hg})$, and a continuation of the inferior vena cava to the azygos vein, all of which were treated conservatively. She was able to sit at the age of 8 months and to walk alone at 1 year (Fig. 1).

At the age of 4.5 years, her general appearance was that of a thin, very small, non-cyanotic girl. Her weight was $9 \mathrm{~kg}(-3.8$ S.D. $)$ and height $87 \mathrm{~cm}(-4.5$ S.D. $)$. Upon examination, the child presented with reduced subcutaneous fat, triangular small face, up-slanting palpebral fissures, slight convergent strabismus, arched eyebrows, low-set ears, high-arched palate, brittle and eroded teeth, microretrognathism, pterygium colli, clinodactyly without flexion crease of the fifth fingers and gap between first and second toes. External genitalia and ophthalmological examination were unremarkable. An echocardiography at that time showed a closed FO, restrictive VSD with bulging of tissue of the tricuspid valve, and normalized left 

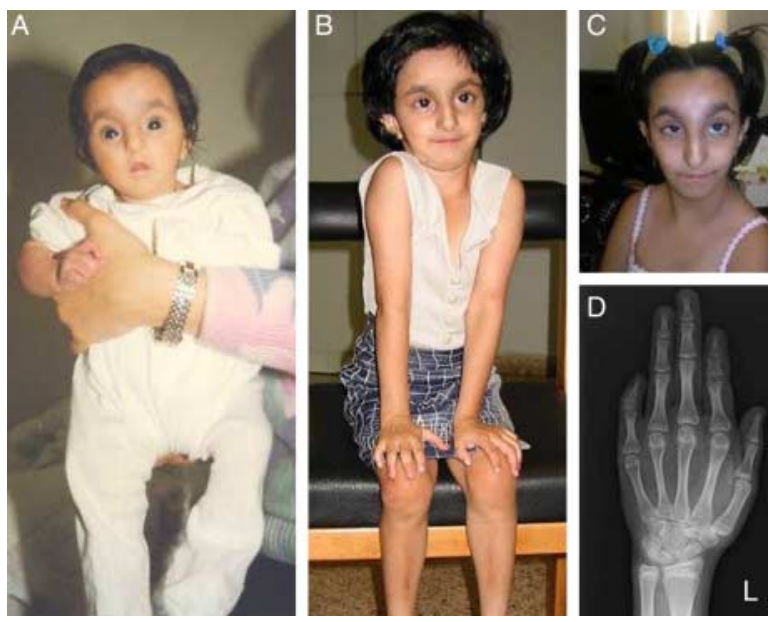

Figure 1 Photographs of the patient at the age of $(A) 2$ months, (B) 9 years, (C) 13.5 years, and (D) X-ray of patient's bone age at 13.5 years. Full colour version of this figure available via http://dx. doi.org/10.1530/EJE-12-0701.

pulmonary artery diameter while the right one was still below normal values. The gradient at that level was about $50 \mathrm{~mm} \mathrm{Hg}$. Bone age was delayed by 6 months.

The patient was seen again when she was 13.5 years old (Fig. 1). She was pleasant and showed a joyful mood. Her voice was high pitched. She started regular school but she so far had to repeat 2 years in her schooling. Her general aspect was unchanged. Auxological parameters were still below the third centile for age (height $135 \mathrm{~cm}$ $(-4.4$ S.D.), weight $30 \mathrm{~kg}(-3.2$ S.D.), and head circumference $(-5.6$ s.D. $))$. An axillary acanthosis nigricans was noted, as well as a mild scoliosis and a truncal obesity. Her pubertal staging was Tanner B2P2, and her bone age corresponded to a chronological age of 15 years (Fig. 1) as determined by the Greulich-Pyle method (26).

Within the family, no other subjects were reported to be born with intrauterine growth failure and/or showed postnatal growth retardation. Her father's height was $173 \mathrm{~cm}$ (-0.66 S.D.) and her mother was $161 \mathrm{~cm}$ $(-0.4$ s.D. $)$ tall. The subject's midparental target height of $160.5 \mathrm{~cm}$ was calculated from the heights of her parents.

\section{Laboratory results}

At 13.5 years old, when last seen, a fasting blood sample was collected for all measurements. Levels of free $\mathrm{T}_{4}$ and TSH were normal. IGF1 level was very high $(950 \mathrm{ng} / \mathrm{ml}$ $(+7$ s.D. $))$, while IGFBP3 was at the upper limit of normal $(8.9 \mathrm{mg} / \mathrm{l}(3.1-9.5))$ and the basal GH was normal $(0.86 \mathrm{ng} / \mathrm{ml})$. Respective values of FSH, LH, and $\mathrm{E}_{2}$ were 4.2, $2.9 \mathrm{IU} / \mathrm{l}$, and $39.4 \mathrm{pg} / \mathrm{ml}$ confirming onset of puberty. The fasting glucose level was normal $(4.7 \mathrm{mmol} / \mathrm{l})$, but baseline insulin levels were high ( $38 \mathrm{mIU} /$; normal value $<25 \mathrm{mIU} / \mathrm{ml}$ ) resulting in a HOMA-IR of 8.0 and thus indicating insulin resistance. Triglyceride levels were elevated ( $2.41 \mathrm{mmol} / \mathrm{l}$; normal values $<1.70 \mathrm{mmol} / \mathrm{l})$. A $50 \mathrm{~g}$ oral glucose tolerance test (OGTT) was performed; at $2 \mathrm{~h}$, the glucose level was $7.4 \mathrm{mmol} / \mathrm{l}$ and the insulin level $277 \mathrm{mIU} / \mathrm{l}$ (respective normal values $<7.7 \mathrm{mmol} / \mathrm{l}$ and $<150 \mathrm{mIU} / \mathrm{l})$. Testosterone level was normal $(<20 \mathrm{ng} / \mathrm{ml})$. A slightly elevated calcium level (2.62 mmol/l, normal range 2.10-2.55) was noted associated with a slightly high phosphorus level (1.63 mmol/l, normal range 0.81-1.45), a normal PTH value $(20 \mathrm{pg} / \mathrm{ml}$, normal range of 6-36), a normal $25(\mathrm{OH}) \mathrm{D}$ level $(28.9 \mathrm{ng} / \mathrm{ml})$, and a high-normal $1,25(\mathrm{OH}) 2 \mathrm{D}$ level $(79 \mathrm{pg} / \mathrm{ml}$, normal range $18-71)$. The IGF1 measurement in the patient's mother was $201 \mathrm{ng} / \mathrm{ml}$ (+0.7 s.D. $)$.

\section{Genetic results}

Chromosome studies of lymphocytes with highresolution G- and R-banding were normal $(46, \mathrm{XX})$. No pathogenic copy number variation $(\mathrm{CNV})$, neither gain nor loss, was detected using the Whole-Genome 2.7M Array.

Sanger sequencing of the IGF1R gene led to the identification of a homozygous variation in exon 2: c.119G $>$ T (Fig. 2). Both parents were heterozygous carriers of the mutation. No aberrations or polymorphisms were observed in the IGF1 gene.

At the protein level, the IGF1R c.119G $>$ T mutation is deduced to be a missense mutation, leading to the replacement of an arginine by a leucine at residue 10 (p.Arg10Leu). The amino acid exchange was predicted to be damaging according to PolyPhen and was absent in 150 Lebanese control chromosomes, thus suggesting a pathogenic impact of the variation. It affects an amino acid residue that is highly conserved among vertebrates, located in the ligand binding L1 domain. Introduction of the p.Arg10Leu mutation into the crystal structure model of the IGF1R ectodomain demonstrates the loss of hydrogen bonds between Leu10 and Asp8 in the mutant IGF1R (Fig. 3).

\section{Functional results}

To assess the impact of the leucine for arginine substitution on the biochemical properties of the receptor, skin fibroblasts of the patient and two sex(control 1) and age (control 1 and 2)-matched control individuals were stimulated with increasing amounts of rhIGF1. Immunoblotting against tyrosine residues within the IGF1R $\beta$-subunit activation loop that become phosphorylated in response to IGF binding revealed diminished but not abrogated autophosphorylation in patient's fibroblasts. Total expression of the mutant IGF $1 R$ was unaffected (Fig. $4 \mathrm{~A}$ and B). The activated IGF1R initiates a signaling cascade by binding and tyrosine phosphorylation of downstream molecules that 


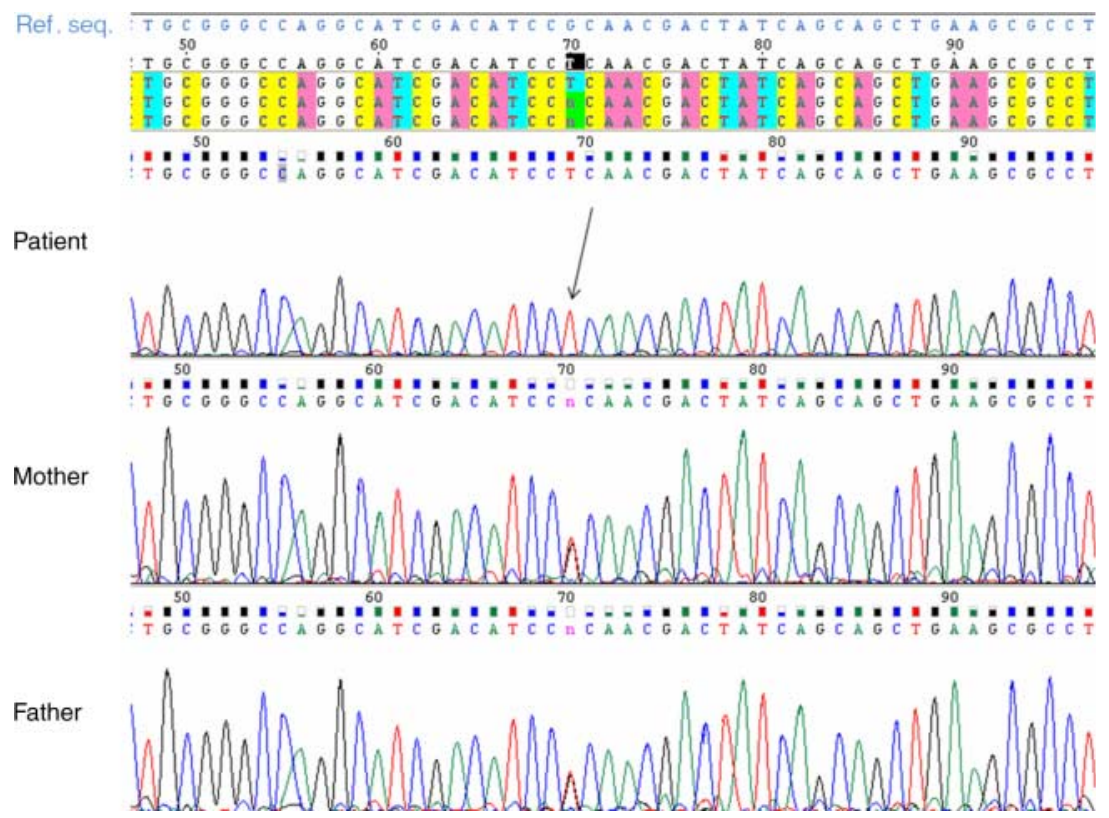

Figure 2 Electropherograms of the patient and her parents showing the replacement of the guanine by a thymine at position 119 (arrow) in exon 2 of $\operatorname{IGF1R}$ (c.119G $>\mathrm{T}$ ). Full colour version of this figure available via http://dx.doi.org/10.1530/EJE-12-0701. ultimately leads to the activation of major signaling nodes such as the protein kinase B/AKT. In patient's fibroblasts, impaired IGF-dependent receptor activation was paralleled by a requirement for higher IGF1 doses to achieve similar levels of AKT phosphorylation compared with control cells (Fig. 4C and D).

\section{Discussion}

Here, we report the case of a 13.5-year-old girl with IUGR, postnatal growth failure, mild developmental delay, dysmorphic facial features, clinodactyly, heart malformations, and insulin resistance. IGF1R analysis revealed the presence of a novel missense mutation in exon 2 in the homozygous state.

Few patients with IGF1R mutations have been reported $(8,9,10,11,12,13,14,15,16,17,18$, $19,20,21)$. In all of them except two $(8,20)$, mutations were in the heterozygous state. Patients were born small for gestational age with a birth weight ranging between -3.4 and -1.5 S.D. and birth length between -5.0 and -0.3 S.D. without postnatal catch-up growth. In addition, some of these patients presented slightly dysmorphic features such as triangular shape of the face, microcephaly, clinodactyly, small hands and feet, and proximally placed thumbs $(8,14,17)$. Mild delay of mental and psychomotor development has been reported for some cases $(8,13,16)$.

Compared with most heterozygous patients with IGF1R mutations, our patient has a more severe growth delay and thus resembles in her auxological characteristics the compound heterozygous patients reported so far $(8,20)$. She also shares with these patients several facial and developmental abnormalities including dental anomalies and mild developmental delay.
Additional findings that were observed in at least one of the compound heterozygous siblings reported by Fang et al. (20) and our homozygous patient were mild facial dysmorphisms, clinodactyly, and convergent strabismus. Moreover, our patient was born with a cardiac defect - a finding that is frequently observed in carriers of heterozygous $15 \mathrm{q} 26$ deletions (including the IGF1R locus) but has been ascribed to genes located proximally to the IGF1R gene (22). However, SNP array analysis in our patient did not show any pathogenic $\mathrm{CNV}$ and, thus, the cause of the heart defect remains elusive.

Interestingly, our patient presented with several metabolic abnormalities. Symptoms of insulin resistance such as high baseline and post-OGTT insulin levels, hypertriglyceridemia, loss of adipose tissue, and acanthosis nigricans were noted. The IGF1R protein shares high homology in structure with the insulin receptor (IR) and activates comparable downstream signal transduction pathways (27). It has also been demonstrated that the IGF1R can form hybrid receptors with the IR with crucial consequences for ligand specificity and signaling capabilities (28). In two previous studies, enhanced IR activation was observed in parallel with a reduction of the IGF1R protein dose $(11,12)$. However, in both patients, abnormalities in glucose metabolism have not been observed. In contrast, reports of other patients with an IGF1R defect revealed an $\mathrm{HbAlc}$ in the upper normal range in one subject (16), mild insulin resistance in another patient (11), or suggested an association between a heterozygous IGF1R nonsense mutation found in several members of an Italian family with variable alterations in carbohydrate metabolism (19). Most interestingly, the compound heterozygous IGF1R patient recently reported by Fang et al. (20) presented with symptomatic 

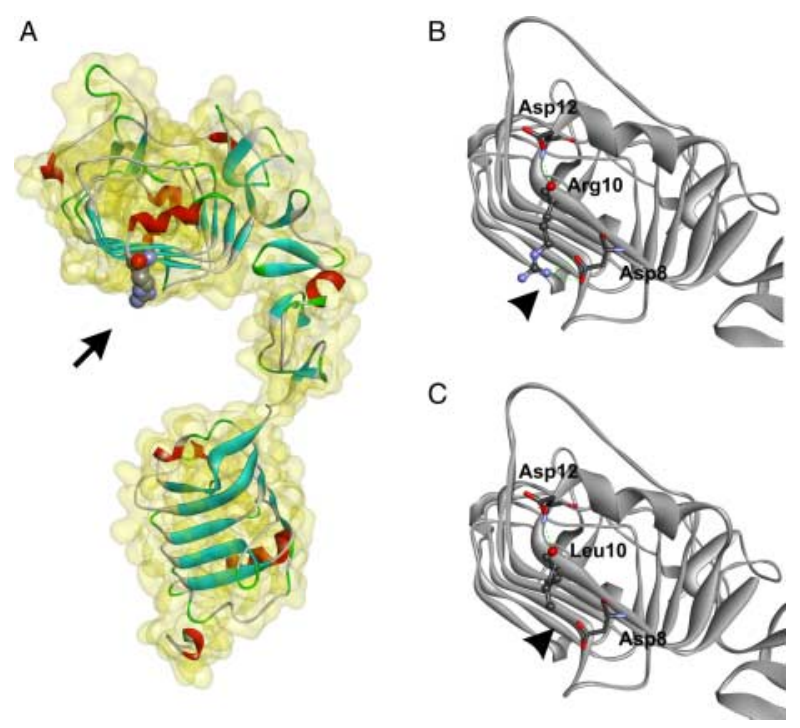

Figure 3 Visualization of the three-dimensional structure of the human IGF1R ectodomain (PDB accession number: 1IGR).

(A) The affected arginine residue at position 10 (arrow) resides at the surface of the L1-Cys-rich (CR)-L2 IGF binding pocket; molecule is shown as ribbon diagram superimposed by the solvent surface; atoms of arginine 10 are displayed as van der Waals spheres. (B and C) Replacement of Arg10 by leucine (arrow heads) results in the loss of hydrogen bonds (dashed lines) to the essentia IGF-interacting aspartic acid residue at position 8 (32). Arg10Leu displayed as ball-and-stick, Asp8 as stick representation. Graphics generated using the free version of Accelrys' Discovery studio 3.0. Full colour version of this figure available via http://dx.doi.org/10. 1530/EJE-12-0701.

diabetes mellitus; although in contrast to our patient, the basis for diabetes appeared to be primary insulin deficiency. Mice expressing a dominant-negative Igflr in skeletal muscle develop hyperinsulinemia at an early age with normal glucose levels, which later on evolves to hyperglycemia and overt diabetes (29). Furthermore, defects in the insulin secretion of pancreatic $\beta$-cells were observed in these mice, which is in line with findings in a mouse model of $\beta$-cell-specific deletion of the Igf1r gene (30). The distinct manifestations of disturbed glucose homeostasis observed in our patient and that reported by Fang might thus be a reflection of the multifaceted functions and complex interactions of the IGF1R as a cofactor in the etiology of type 2 diabetes in different tissues. Thus, although pieces of information are accumulating that point to a direct interrelationship between IGF1R mutations and a disturbed glucose homeostasis in affected patients, direct evidence is still lacking and more specific studies, particularly in typical insulin-responsive tissues, are necessary.

In addition, so far, we do not have any plausible explanation for the accelerated bone age as the patient presented no signs of an accelerated puberty nor elevated endogenous GH. Hyperinsulinism may play a role as obese children have some bone advancement.

Lastly, the slightly elevated calcium despite a normal PTH level might suggest a role for the GH/IGF1 system in calcium metabolism. High calcium level with normal PTH has been described in two acromegalic patients in whom the hypercalcemia was $1,25(\mathrm{OH}) 2 \mathrm{D}$ dependent (31). Whether excess GH or IGF1 increases the production of $1,25(\mathrm{OH}) 2 \mathrm{D}$ in humans remains to be elucidated.

Receptor activation studies using patient's fibroblasts demonstrated an impaired capability of the mutant Arg10Leu receptor to tyrosine-phosphorylate itself and to activate the AKT downstream signaling pathway. However, the underlying mechanism remains speculative. By analogy to the hormone-receptor interface of insulin/IR, the highly conserved Arg10 of the IGF1R was initially suggested to be directly involved in ligand binding (25). However, alanine scanning experiments did not confirm such an assumption (32). Replacement

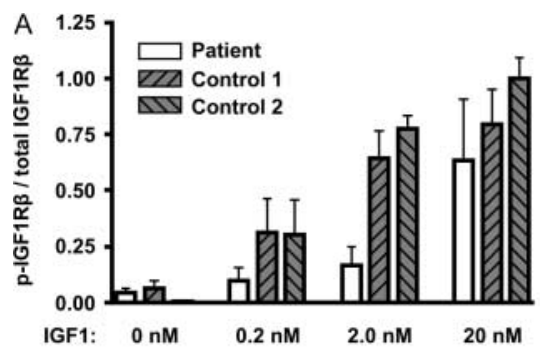

B

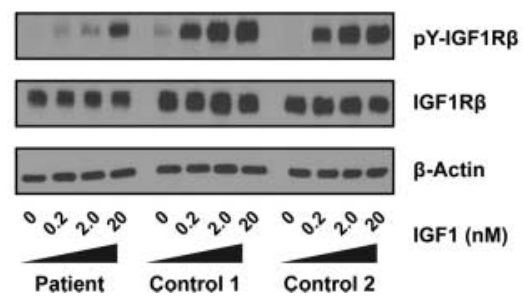

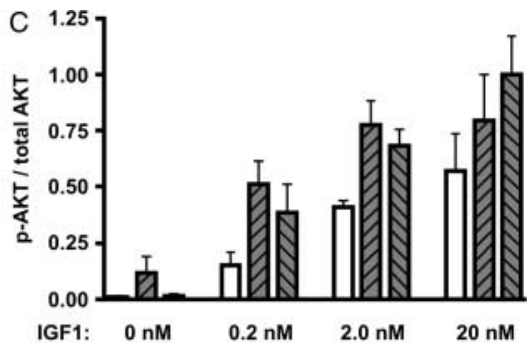

D

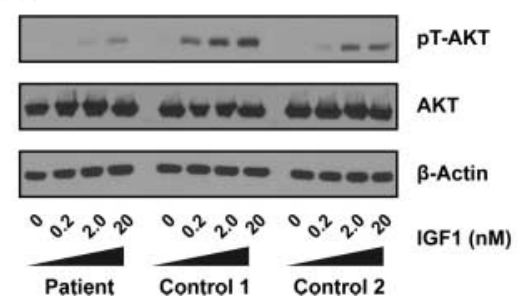

Figure 4 The IGF1R Arg10Leu mutation impairs IGF1-dependent IGF1R autophosphorylation and downstream signaling. Skin fibroblasts of the patient and two control subjects were stimulated with increasing amounts of IGF1 as described in the Subjects and methods section. Immunoblots were densitometrically quantified and normalized to total IGF1R (A) or AKT (C) expression. Control 2 stimulated with $20 \mathrm{nM}$ rhlGF1 was set to 1 ; the mean of three independent experiments \pm S.E.M. is shown. (B and $D)$ Depict representative experiments showing diminished IGF1 dose-dependent autophosphorylation of the mutant IGF1R $\beta$-subunit (pY-IGF1R $\beta$ ) and reduced AKT phosphorylation at threonine residue 308 (pT-AKT) compared with wild-type controls with unaffected total IGF1R $\beta$ and AKT expression respectively. Immunoblotting against $\beta$-actin was performed as loading control. 
of $\operatorname{Arg} 10$ by the branched chain amino acid leucine instead of alanine, however, might have more detrimental consequences for IGF binding (Fig. 3). Other mechanisms, such as impaired plasma membrane trafficking, might also contribute to the reduced IGF1 response.

Reconstitution studies of previously reported heterozygous mutations have shown that most of them result in a complete loss of function. However, receptors expressed from the wild-type allele in these patients can be assumed to partly compensate for the aberrant allele. Moreover, due to the composition of the IGF1R of two (hemi)receptor halves, a substantial proportion of receptors will be assembled out of two wild-type receptor species assuring residual receptor activity. To date, homozygous mutations have not been described in humans, but mice null mutants for the Igf $1 r$ gene invariably die at birth from respiratory failure (33). Thus, we suggest that only hypomorphic IGF1R mutations in a homozygous state as found in our patient are compatible with life, whereas loss-of-function mutations affecting both IGF1R alleles can be expected to be lethal.

Finally, we suggest that the asymptomatic phenotype of both parents, despite the presence of a heterozygous mutation, is the consequence of the hypomorphic nature of the Arg10Leu variant. Across all the family generations, there was no report of intrauterine or postnatal growth failure. From our results, it can be concluded that the great phenotypic variability observed in patients with IGF1 resistance is not only caused by the genetic background and/or environmental factors but also due to the type of mutations that influence the severity of the phenotypic appearance (10).

In conclusion, we describe for the first time a homozygous mutation of the IGF1R gene in a 13.5year-old girl. This mutation is associated with severe IUGR, intellectual impairment, and an insulin-resistant state. Both parents were heterozygous carriers of the mutation without any clinical consequence, highlighting the possibility of asymptomatic carriers of heterozygous IGF1R mutations.

\section{Declaration of interest}

The authors declare that there is no conflict of interest that could be perceived as prejudicing the impartiality of the research reported.

\section{Funding}

This study was supported by Saint Joseph University (Beirut, Lebanon) and by a grant of the Deutsche Forschungsgemeinschaft (Bonn, Germany; project PF 225/3 to J Klammt and R Pfäffle). R Pfäffle has received research grants from Ferring, Eli Lilly, and Merck Serono and serves on a Lilly advisory board.

\section{Acknowledgements}

The authors would like to thank Maike Ziegler for her excellent assistance in performing the western blotting experiments.

\section{References}

1 Clayton PE, Cianfarani S, Czernichow P, Johannsson G, Rapaport R $\&$ Rogol A. Management of the child born small for gestational age through to adulthood: a consensus statement of the International Societies of Pediatric Endocrinology and the Growth Hormone Research Society. Journal of Clinical Endocrinology and Metabolism 200792 804-810. (doi:10.1210/jc.2006-2017)

2 Saenger P, Czernichow P, Hughes I \& Reiter EO. Small for gestational age: short stature and beyond. Endocrine Reviews 200728 219-251. (doi:10.1210/er.2006-0039)

3 Woods KA, Camacho-Hubner C, Savage MO \& Clark AJ. Intrauterine growth retardation and postnatal growth failure associated with deletion of the insulin-like growth factor I gene. New England Journal of Medicine 1996335 1363-1367. (doi:10.1056/NEJM199610313351805)

4 Bonapace G, Concolino D, Formicola S \& Strisciuglio P. A novel mutation in a patient with insulin-like growth factor 1 (IGF1) deficiency. Journal of Medical Genetics $2003 \quad 40$ 913-917. (doi:10.1136/jmg.40.12.913)

5 Walenkamp MJ, Karperien M, Pereira AM, Hilhorst-Hofstee Y, van Doorn J, Chen JW, Mohan S, Denley A, Forbes B, van Duyvenvoorde HA et al. Homozygous and heterozygous expression of a novel insulin-like growth factor-I mutation. Journal of Clinical Endocrinology and Metabolism 200590 2855-2864. (doi:10.1210/jc.2004-1254)

6 Netchine I, Azzi S, Houang M, Seurin D, Perin L, Ricort JM, Daubas C, Legay C, Mester J, Herich R et al. Partial primary deficiency of insulin-like growth factor (IGF)-I activity associated with IGF1 mutation demonstrates its critical role in growth and brain development. Journal of Clinical Endocrinology and Metabolism 200994 3913-3921. (doi:10.1210/jc.2009-0452)

7 Klammt J, Kiess W \& Pfaffle R. IGF1R mutations as cause of SGA. Best Practice \& Research. Clinical Endocrinology \& Metabolism 2011 25 191-206. (doi:10.1016/j.beem.2010.09.012)

8 Abuzzahab MJ, Schneider A, Goddard A, Grigorescu F, Lautier C, Keller E, Kiess W, Klammt J, Kratzsch J, Osgood D et al. IGF-I receptor mutations resulting in intrauterine and postnatal growth retardation. New England Journal of Medicine 2003349 2211-2222. (doi:10.1056/NEJMoa010107)

9 Walenkamp MJ, de Muinck Keizer-Schrama SM, de Mos M, Kalf ME, van Duyvenvoorde HA, Boot AM, Kant SG, White SJ, Losekoot M, Den Dunnen JT et al. Successful long-term growth hormone therapy in a girl with haploinsufficiency of the insulinlike growth factor- 1 receptor due to a terminal $15 \mathrm{q} 26.2 \rightarrow$ qter deletion detected by multiplex ligation probe amplification. Journal of Clinical Endocrinology and Metabolism 200893 2421-2425. (doi:10.1210/jc.2007-1789)

10 Ester WA, van Duyvenvoorde HA, de Wit CC, Broekman AJ, Ruivenkamp CA, Govaerts LC, Wit JM, Hokken-Koelega AC \& Losekoot M. Two short children born small for gestational age with insulin-like growth factor 1 receptor haploinsufficiency illustrate the heterogeneity of its phenotype. Journal of Clinical Endocrinology and Metabolism 200994 4717-4727. (doi:10.1210/jc.2008-1502)

11 Raile K, Klammt J, Schneider A, Keller A, Laue S, Smith R, Pfäffle R, Kratzsch J, Keller E \& Kiess W. Clinical and functional characteristics of the human Arg59Ter insulin-like growth factor 1 receptor (IGF1R) mutation: implications for a gene dosage effect of the human IGF1R. Journal of Clinical Endocrinology and Metabolism 200691 2264-2271. (doi:10.1210/jc.2005-2146)

12 Fang P. Schwartz ID, Johnson BD, Derr MA, Roberts CT Jr. Hwa V \& Rosenfeld RG. Familial short stature caused by haploinsufficiency of the insulin-like growth factor 1 receptor due to nonsensemediated messenger ribonucleic acid decay. Journal of Clinical Endocrinology and Metabolism 200994 1740-1747. (doi:10. 1210/jc.2008-1903)

13 Kawashima Y, Kanzaki S, Yang F, Kinoshita T, Hanaki K, Nagaishi J, Ohtsuka Y, Hisatome I, Ninomoya H, Nanba E et al. Mutation at cleavage site of insulin-like growth factor receptor 
in a short-stature child born with intrauterine growth retardation. Journal of Clinical Endocrinology and Metabolism 200590 4679-4687. (doi:10.1210/jc.2004-1947)

14 Walenkamp MJ, van der Kamp HJ, Pereira AM, Kant SG, van Duyvenvoorde HA, Kruithof MF, Breuning MH, Romijn JA, Karperien M \& Wit JM. A variable degree of intrauterine and postnatal growth retardation in a family with a missense mutation in the insulin-like growth factor I receptor. Journal of Clinical Endocrinology and Metabolism $2006913062-3070$. (doi:10.1210/jc.2005-1597)

15 Inagaki K, Tiulpakov A, Rubtsov P, Sverdlova P, Peterkova V, Yakar S, Terekhov S \& LeRoith D. A familial insulin-like growth factor-1 receptor mutant leads to short stature: clinical and biochemical characterization. Journal of Clinical Endocrinology and Metabolism 200792 1542-1548. (doi:10.1210/jc.2006-2354)

16 Wallborn T, Wüller S, Klammt J, Kruis T, Kratzsch J, Schmidt G, Schlicke M, Müller E, van de Leur HSKiess Wet al. A heterozygous mutation of the insulin-like growth factor-I receptor causes retention of the nascent protein in the endoplasmic reticulum and results in intrauterine and postnatal growth retardation. Journal of Clinical Endocrinology and Metabolism 201095 2316-2324. (doi:10.1210/jc.2009-2404)

17 Kruis T, Klammt J, Galli-Tsinopoulou A, Wallborn T, Schlicke M, Müller E, Kratzsch J, Körner A, Odeh R, Kiess W et al. Heterozygous mutation within a kinase-conserved motif of the insulin-like growth factor I receptor causes intrauterine and postnatal growth retardation. Journal of Clinical Endocrinology and Metabolism 201095 1137-1142. (doi:10.1210/jc.2009-1433)

18 Choi JH, Kang M, Kim GH, Hong M, Jin HY, Lee BH, Park JY, Lee SM, Seo EJ \& Yoo HW. Clinical and functional characteristics of a novel heterozygous mutation of the IGF1R gene and IGF1R haploinsufficiency due to terminal 15 q26.2 $\rightarrow$ qter deletion in patients with intrauterine growth retardation and postnatal catch-up. Journal of Clinical Endocrinology and Metabolism 2011 96 E130-E134. (doi:10.1210/jc.2010-1789)

19 Mohn A, Marcovecchio ML, de Giorgis T, Pfaeffle R, Chiarelli F \& Kiess W. An insulin-like growth factor-I receptor defect associated with short stature and impaired carbohydrate homeostasis in an Italian pedigree. Hormone Research in Paediatrics 201176 136-143. (doi:10.1159/000324957)

20 Fang P, Cho YH, Derr MA, Rosenfeld RG, Hwa V \& Cowell CT. Severe short stature caused by novel compound heterozygous mutations of the insulin-like growth factor 1 receptor (IGF1R). Journal of Clinical Endocrinology and Metabolism $2012 \mathbf{9 7}$ E243-E247. (doi:10.1210/jc.2011-2142)

21 Kawashima Y, Higaki K, Fukushima T, Hakuno F, Nagaishi JI, Hanaki K, Nanba E, Takahashi SI \& Kanzaki S. Novel missense mutation in the IGF-I receptor L2 domain results in intrauterine and postnatal growth retardation. Clinical Endocrinology 201277 246-254. (doi:10.1111/j.1365-2265.2012.04357.x)

22 Poot M, Eleveld MJ, van 't SR, van Genderen MM, Verrijn Stuart AA, Hochstenbach R \& Beemer FA. Proportional growth failure and oculocutaneous albinism in a girl with a $6.87 \mathrm{Mb}$ deletion of region $15 \mathrm{q} 26.2 \rightarrow$ qter. European Journal of Medical Genetics 200750 432-440. (doi:10.1016/j.ejmg.2007.08.003)

23 Matthews DR, Hosker JP, Rudenski AS, Naylor BA, Treacher DF \& Turner RC. Homeostasis model assessment: insulin resistance and $\beta$-cell function from fasting plasma glucose and insulin concentrations in man. Diabetologia $1985 \mathbf{2 8} 412-419$. (doi:10.1007/ BF00280883)

24 Grimberg J, Nawoschik S, Belluscio L, McKee R, Turck A \& Eisenberg A. A simple and efficient non-organic procedure for the isolation of genomic DNA from blood. Nucleic Acids Research 1989 17 8390. (doi:10.1093/nar/17.20.8390)

25 Garrett TP, McKern NM, Lou M, Frenkel MJ, Bentley JD, Lovrecz GO, Elleman TC, Cosgrove LJ \& Ward CW. Crystal structure of the first three domains of the type-1 insulin-like growth factor receptor. Nature $1998 \mathbf{3 9 4}$ 395-399. (doi:10. 1038/28668)

26 Greulich WW \& Pyle SI. Radiographic Atlas of Skeletal Development of the Hand and Wrist, 2nd edn. Stanford, CA: Stanford University Press, 1959.

27 Nakae J, Kido Y \& Accili D. Distinct and overlapping functions of insulin and IGF-I receptors. Endocrine Reviews 200122 818-835. (doi:10.1210/er.22.6.818)

28 Belfiore A, Frasca F, Pandini G, Sciacca L \& Vigneri R. Insulin receptor isoforms and insulin receptor/insulin-like growth factor receptor hybrids in physiology and disease. Endocrine Reviews 200930 586-623. (doi:10.1210/er.2008-0047)

29 Fernandez AM, Kim JK, Yakar S, Dupont J, Hernandez-Sanchez C, Castle AL, Filmore J, Shulman GI \& Le Roith D. Functional inactivation of the IGF-I and insulin receptors in skeletal muscle causes type 2 diabetes. Genes and Development 200115 1926-1934. (doi:10.1101/gad.908001)

30 Kulkarni RN, Holzenberger M, Shih DQ, Ozcan U, Stoffel M, Magnuson MA \& Kahn CR. $\beta$-Cell-specific deletion of the Igf1 receptor leads to hyperinsulinemia and glucose intolerance but does not alter $\beta$-cell mass. Nature Genetics 200231 111-115.

31 Shah R, Licata A, Oyesiku NM \& Ioachimescu AG. Acromegaly as a cause of 1,25-dihydroxyvitamin D-dependent hypercalcemia: case reports and review of the literature. Pituitary 2012 In press.

32 Whittaker J, Groth AV, Mynarcik DC, Pluzek L, Gadsboll VL \& Whittaker LJ. Alanine scanning mutagenesis of a type 1 insulin-like growth factor receptor ligand binding site. Journal of Biological Chemistry 2001276 43980-43986. (doi:10.1074/jbc. M102863200)

33 Liu JP, Baker J, Perkins AS, Robertson EJ \& Efstratiadis A. Mice carrying null mutations of the genes encoding insulin-like growth factor I (Igf-1) and type 1 IGF receptor (Igf1r). Cell 1993 75 59-72.

Received 14 August 2012

Revised version received 1 October 2012

Accepted 8 October 2012 